\title{
Feeding Behavior in Ibisbill (Ibidorhyncha struthersii)
}

\author{
Iqram Ul Haq ${ }^{1, *}$, Bilal A. Bhat ${ }^{1}$, Khursheed Ahmad ${ }^{2}$ \\ ${ }^{1}$ Biodiversity Conservation Lab, Department of Zoology, University of Kashmir, India \\ ${ }^{2}$ Division of Wildlife Sciences, Sher-e-Kashmir University of Agricultural Sciences and Technology of Kashmir, India
}

Received December 7, 2020; Revised January 9, 2021; Accepted March 12, 2021

\section{Cite This Paper in the following Citation Styles}

(a): [1] Iqram Ul Haq, Bilal A. Bhat, Khursheed Ahmad, "Feeding Behavior in Ibisbill (Ibidorhyncha struthersii)," Advances in Zoology and Botany, Vol. 9, No. 2, pp. 60 - 64, 2021. DOI: 10.13189/azb.2021.090204.

(b): Iqram Ul Haq, Bilal A. Bhat, Khursheed Ahmad (2021). Feeding Behavior in Ibisbill (Ibidorhyncha struthersii). Advances in Zoology and Botany, 9(2), 60 - 64. DOI: 10.13189/azb.2021.090204.

Copyright $\bigcirc 2021$ by authors, all rights reserved. Authors agree that this article remains permanently open access under the terms of the Creative Commons Attribution License 4.0 International License

\begin{abstract}
Feeding behaviour of Ibisbill was studied in the Kashmir Himalayan River Sindh. Observations on the foraging behaviour were made at six selected sites. The food items consumed by the bird during the study period include aquatic invertebrates, insects, and fishes of smaller size. In a novel finding, the bird was found to feed on a vole $(n=2)$. The main technique used for obtaining prey items was probing, however, pecking was also employed for feeding the larger prey items. A total of 820 observations revealed that the foraging accounted for about $44 \%$ of activity time budget in summer while as in winter the foraging was found to contribute to about $62 \%$. Diurnal behavioral rhythms of foraging showed a peak during morning hours (8:00 to 10:00) in summer and in winter the peak was observed during the afternoon (12:00 to $15: 00)$. The probing rate was higher $(19.23 \pm 0.70)$ in winter and lower $(17.39 \pm 0.67)$ in summer, whereas an inverse trend was observed for capture rate which was higher in summer $(8.61 \pm 0.46)$ and lower $(5.86 \pm 0.27)$ in winter. The Sindh river was also found to witness anthropogenic activities such as extensive mining (extraction of sand, silt and boulders) and tourism related activities, having a negative impact on the habitat of the bird. From the conservation viewpoint, these habitat impacting activities in this river shall be controlled, to ensure better feeding conditions for Ibisbill and other waterbirds.
\end{abstract}

Keywords Ibisbill, Foraging, Kashmir-Himalaya, Sindh River, Aquatic Invertebrates

\section{Introduction}

ibidorhynchidae) commonly known as Ibisbill, is a large wader inhabiting the shingle bed Rivers of Central Asia. Its range is centered on the Pamirs, Himalayas and the Tibetan plateau with some populations occurring west to Turkistan, east to northern Myanmar [1, 2]. The ideal habitat of Ibidorhyncha struthersii comprises shingle bed river valleys in the altitudinal range of $1700-3400 \mathrm{~m}$ with intermittent stretches of sand and silt, boulders, cobbles, and pebbles [3]. The distribution of Ibidorhyncha struthersii in India is restricted to a few places in the Himalayas and records of sightings have been invariably very rare [4]. It is a resident bird of Himalayan Rivers and migrates to lower altitudes in winter.

Understanding the feeding ecology, habitat utilization and strategies play a pivotal role in bird conservation as the food quality and abundance of prey items have a direct impact on the distribution pattern and habitat site selection of species [5, 6]. Furthermore, the availability of prey items significantly impacts the survival, growth, and reproductive success of birds [7, 8]. The Feeding behavior of Ibidorhyncha struthersii is poorly studied [2]. A few studies have shown that the diet of the bird mainly consists of insects, molluscs, crustaceans, worms, and possibly fish [1, 9]. However, there has been very little information on general foraging patterns of Ibidorhyncha struthersii across its geographical range and scanty information is available on its feeding ecology in Indian Himalayas. The current study was therefore conducted to study the feeding ecology of Ibisbill, Ibidorhyncha struthersii in River Sindh of northwestern Himalayas.

\section{Ibidorhyncha struthersii (Charadriiformes, 2. Methodology \\ Ibidorhyncha struthersii (Charadriiformes, 2. Methodology}




\section{Study Area:}

The study was conducted in River Sindh, district Ganderbal located at $34.23^{\circ} \mathrm{N}$ and $74.78^{\circ} \mathrm{E}$, with an average elevation of $1619 \mathrm{~m}$ [10]. River Sindh, a major tributary of River Jehlum has a course of about $100 \mathrm{~km}$ with a basin area exceeding $1559 \mathrm{~km}^{2}$. The river originates from Panjtarni snowfields $(4250 \mathrm{~m}$ asl) and receives ample flow from the Amarnath (5003m asl), Kolahoi (5425m asl), and Thajwas Glacier (3000m asl) as well. Sindh is a fast-flowing torrential river in its upper and middle reaches while in the lower reaches it becomes calm and flows slowly [11]. The River comprises small islands all along its course dominated by the presence of huge rocks in the upper stretches. The beds of River Sindh comprise mainly of cobbles, boulders, with some underlying pebbles and sand and silt at few places as well, serving as an ideal habitat for riverine birds. However, the River witnesses a huge anthropogenic pressure in the form of activities like mining (sand-boulder extraction), grazing, pollution, and a heavy impact from large-scale tourism.

\section{Sampling}

Data were collected to explore the food and feeding habits of Ibisbill in River Sindh during winter 2018 and summer 2019. A total of six sites were selected for observations, depending on the presence of the bird (Figure 1). The observations on the foraging behavior were made from a vantage point providing an unobstructed view of the sampling area and more importantly did not disturb the closest bird in all the selected sites. Focal animal sampling method was employed $[12,13]$ for recording the observation using binoculars $(10 \times 50 \mathrm{X})$, telescopes $(25 \times 40)$, and the bird was also video tapped [14] while foraging. On-site inspection of feeding patch was made to identify the food items and types of prey. The leftover prey items were also collected for identification.

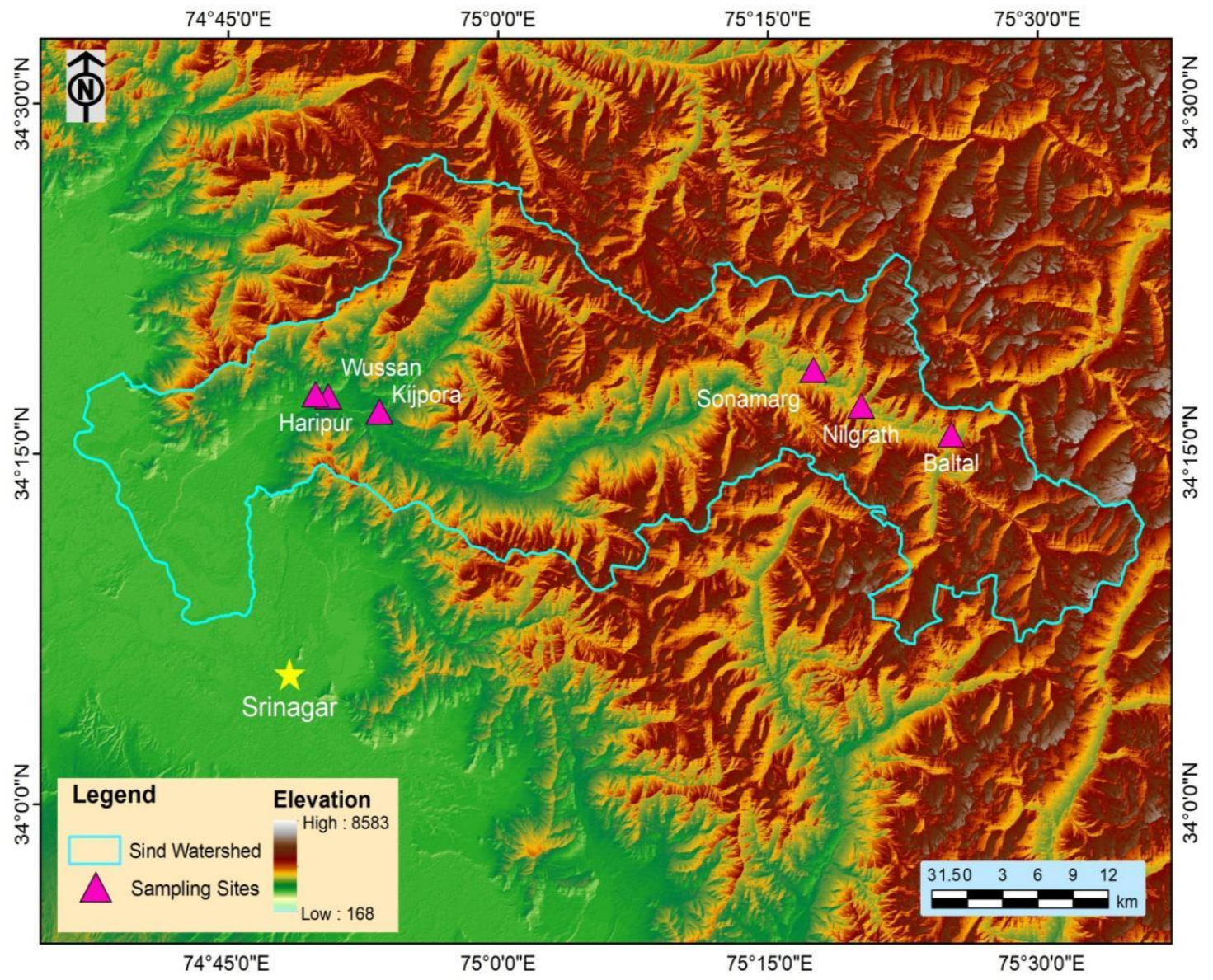

Figure 1. GIS map of the study area 


\section{Results}

Ibisbill is a ground feeder and feeds only during the day time ( $n=820$ observations). Ibisbill roosts on the areas where the shingle beds are covered on all sides by water. The bird was observed to start feeding at dawn and stop at dusk. Besides feeding, the bird was also found to perform other behavioral activities like resting, locomotion, alert, and other maintenance activities.

During summer the foraging contributed to about $44 \%$ of the activity time budget while in winter the foraging was found to contribute to about $62 \%$ of the activity time budget (Figure 2). In summer, the diurnal behavioral rhythm for foraging showed a maximum peak in the morning hours (8:00 to 10:00), however, in winter, the maximum peak was observed in the afternoon (12:00 to 15:00) Figure 3.

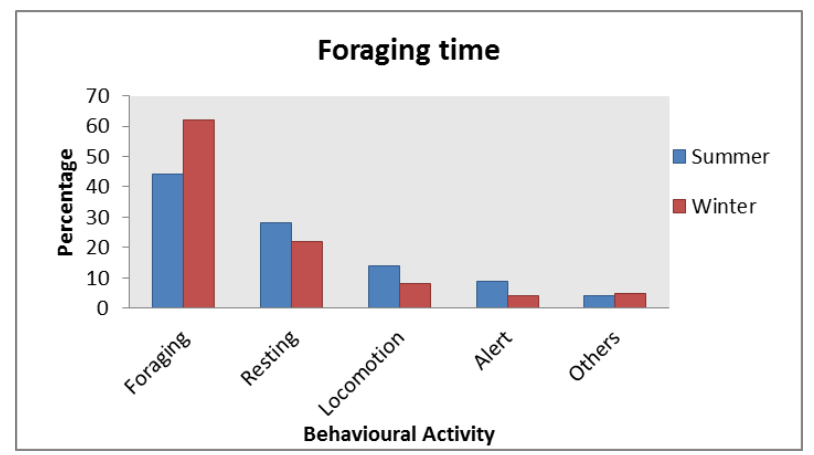

Figure 2. Activity time budget of Ibisbill

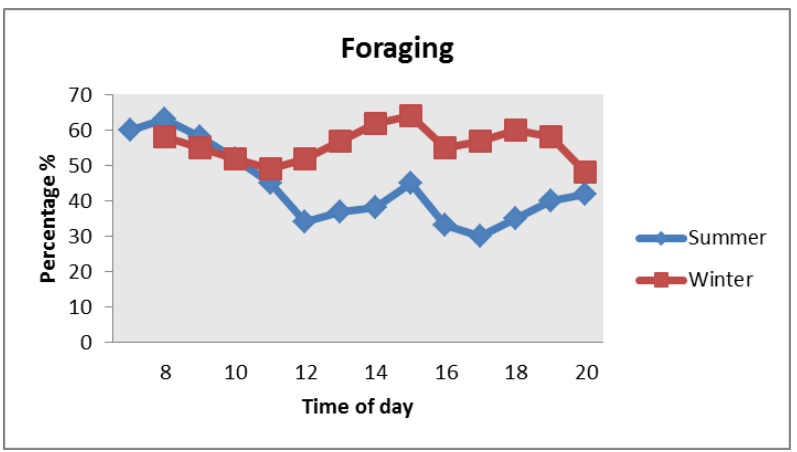

Figure 3. Day time foraging rhythm of Ibisbill in summer and winter

The current study revealed that the probing rate was high $(19.23 \pm 0.70)$ in winter and less $(17.39 \pm 0.67)$ in summer, whereas an inverse trend was observed for capture rate which was higher in summer $(8.61 \pm 0.46)$ and less $(5.86 \pm 0.27)$ in winter (Table 1$)$.

Ibidorhyncha struthersii occupies a particular habitat patch and feeds for hours ( 2 to 3 hours) on the same patch unless disturbed. The bird often walks in an unordered way in the foraging area, performing activities like probing, standing, pecking, head underwater, wing flicking, walking slowly, and swimming. In summer, the bird was found to feed on the riparian areas and agricultural fields as well, however, in winter the feeding activity was mainly observed in the water. While feeding on riparian and agricultural fields, the prey items were obtained by flipping, walking slowly and walking quickly whereas probing and pecking techniques were mainly used for foraging in water.

Table 1. Capturing success in relation to probing rate and pace rate of Ibsibill in summer and winter

\begin{tabular}{|c|c|c|c|c|c|c|}
\hline \multirow[t]{2}{*}{ Variables } & \multirow{2}{*}{$\begin{array}{c}\text { Summer } \\
\text { Mean }\end{array}$} & \multicolumn{5}{|c|}{ Winter } \\
\hline & & SE & $\mathrm{N}$ & Mean & SE & $\mathrm{N}$ \\
\hline Probing/min & 17.39 & \pm 0.67 & 18 & 19.23 & \pm 0.70 & 22 \\
\hline Pace/min & 16.22 & \pm 0.94 & 18 & 12.09 & \pm 0.55 & 22 \\
\hline Capture/min & 8.61 & \pm 0.46 & 18 & 5.86 & \pm 0.27 & 22 \\
\hline
\end{tabular}

$\mathrm{SE}=$ Standard error

Table 2. Prey items consumed by Ibisbill

\begin{tabular}{cccc}
\hline S.No. & Food & Order-family & Species \\
\hline 1 & Fish & Cypriniformes- Nemacheilidae & Triplophysa kashmirensis \\
T. marmorata & Gammarus pulex \\
2 & Crustacean & Amphipoda & Elmida sp. \\
& & Coleoptera & UI \\
3 & Beetle & Corydailidae & UI \\
& & Hydrophilidae & Baetis larva \\
4 & Mayfly & Heteroceridae & Epeorus larva \\
5 & Caddisfly & Ephemeroptera & Rhyacophila sp. \\
7 & Stonefly & Tricoptera & Perlidae sp. \\
8 & Leech & Plecoptera & Erpobdella sp. \\
9 & Ant & Annelida & UI \\
\end{tabular}

UI: unidentified 

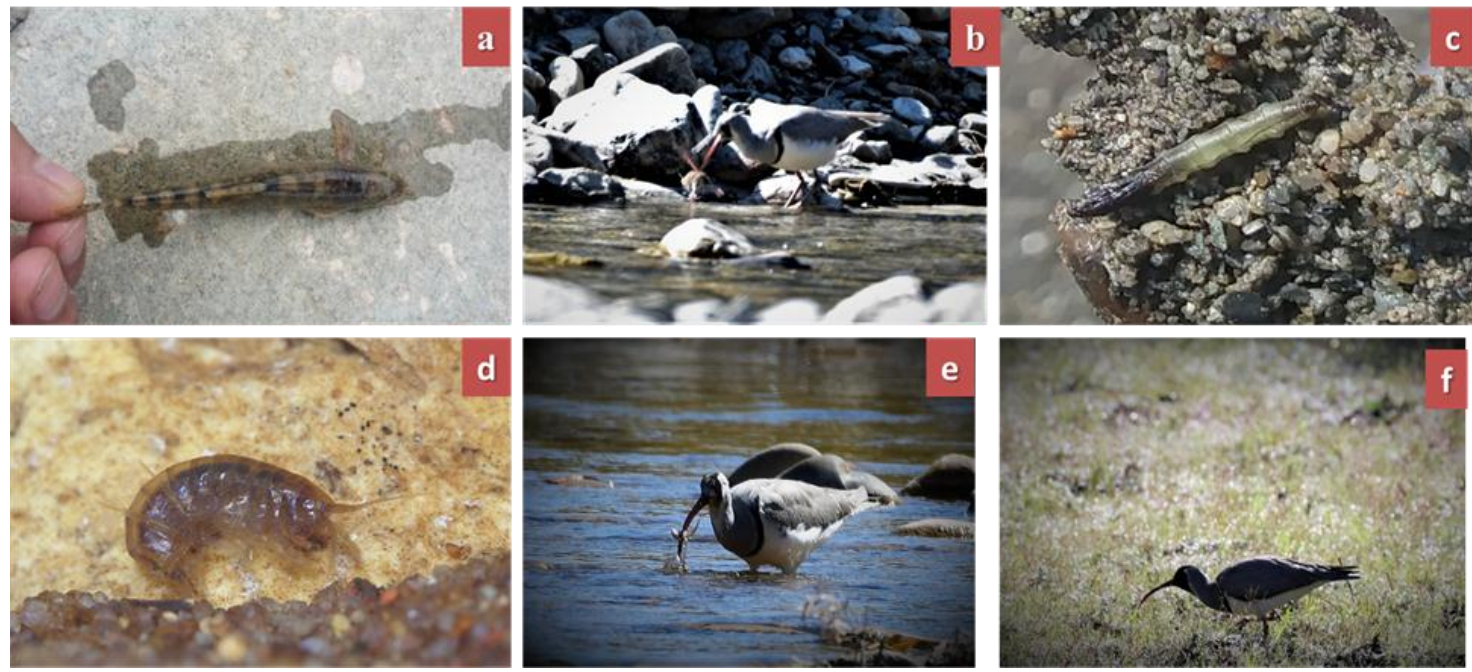

Figure 3. a) Triplophysa kashmirensis b) Ibisbill feeding on vole c) Heteroceridae larva d) Gammarus pulex e) Ibisbill feeding on fish and f) Ibisbill feeding in the riparian area

\section{Prey items consumed}

In studies so far the diet composition of Ibisbill has been shown to include small invertebrates (insects, crustaceans, worms, molluscs) and possibly fish $[1,9]$ (Baker 1929, Ali \&Ripley 1969) however, our study confirms the fact that the bird feeds on fishes as well. Only live prey items were consumed by the bird. Fishes of $<3 \mathrm{~cm}$ of size were easily taken by swallowing and those of larger size $(>5 \mathrm{~cm})$ were pecked multiple times $(35-40$ pecks, $n=10$ ) depicting the piscivorous nature of the bird. During our observation, the fish was mostly consumed during winter $(n=20)$. The food items consumed by the bird during the study period are included in (Table 2, Figure 3). In a novel finding, the bird was found to feed on a vole $(n=2)$.

\section{Discussion}

Shorebirds mainly employ two techniques for foraging. In substrate, they obtain food through tactile feeding and employ visual pecking technique for surface feeding [15]. In the present study, the Ibisbill was mainly found to obtain its food by probing such observations are also reported in other waders with long bills [16]. In terms of foraging success, the probing has been considered more important than pecking for the easy capture of prey [17]. The shape and length of the bill have a direct impact on the foraging behavior [18, 19], habitat selection and choice of the diet [20,21]. Ibisbill has a long, downward curved bill, which is morphologically adapted for capturing the prey in shingle river beds. Similar observations have also been previously reported [2]. Moreover, the study confirms the piscivorous nature of the bird mostly during winter, this might be due to a decrease in the Invertebrate diversity during winter months.

Foraging behavior of the Ibisbill showed a marked variation between summer and winter spending more time on feeding and related activities in winter than in summer, similar observations were also made by [3]. The main reason for such behavior as per our observation is due to the decreased availability of feeding habitats requiring more effort.

To cope up with the change in the availability of food items the birds usually change their foraging strategies [22] as the animals chose the most profitable prey items for optimal foraging [23]. The foraging started late in the morning during winter and showed a peak in the afternoon (12:00 to $15: 00 \mathrm{hrs})$ rather than in the morning (08:00 to 10:00hrs) possibly because of less availability of the feeding grounds in winter as the shallow waters remain frozen till late morning. The more consumption of fish in winter may be attributed to the decline in the availability of the prey preferred during other seasons and needs further investigation. Our results indicate that River Sindh provides a quality feeding area for Ibisbill and probably other waders. The long-term deterioration of feeding conditions for habitat-specific waders may affect the population and can adversely affect the reproductive success of individuals [24]. The Sindh River was also found to witness anthropogenic activities such as extensive mining (extraction of sand, silt and boulders) and tourism related activities, having a negative impact on the habitat of the bird. From the conservation viewpoint, these habitat impacting activities in this river shall be controlled, to ensure better feeding conditions for Ibisbill and other waterbirds.

\section{Acknowledgments}

We are grateful to the Department of Wildlife 
Protection, Jammu and Kashmir for their cooperation. We would also particularly like extend thanks to Head, Department of Zoology. Thanks are given to Dr. Riyaz Ahmad (Wildlife Trust of India) and Sabeehah Rehman (CORD, University of Kashmir) for their valuable suggestions.

\section{REFERENCES}

[1] S. Ali, S.D. Ripley. Handbook of the birds of India and Pakistan, Oxford University press, Vol. 2, 1969.

[2] R.J. Pierce. Observations on behavior and foraging of the Ibisbill Ibidorhyncha struthersii in Nepal, Ibis, Vol. 128(1), 37-47, 1986.

[3] Y. Ye, G.W. Davison, P. Zhu, L. Duan, N. Wang, S. Xing, C. Ding. Habitat Utilization, Time Budget and Daily Rhythm of Ibisbill (Ibidorhyncha struthersii) in Daocheng County, Southwest China, Waterbirds, Vol. 36(2), 135-143, 2013.

[4] R. Grimmett, C. Inskipp, T. Inskipp. Birds of the Indian Subcontinent. 2nd ed. London: Oxford University Press \& Christopher Helm. Pp. 1-528, 2011.

[5] K.J. Benoit-Bird, B.C. Battaile, S.A. Heppell, B. Hoover, D. Irons, N. Jones, K.J. Kuletz, C.A. Nordstorm, R. Paredes, R.M. Suryan, C.M. Waluk. Prey patch patterns predict habitat use by top marine predators with diverse foraging strategies, PLoS One, Vol. 8(1), e53348, 2013.

[6] P.K. Saikia. Ecobiology of Adjutant Storks with Special reference to Leptoptilos javanicus (Horsfield) in The Brahmaputra valley Assam, Doctoral dissertation, PhD Thesis. Gauhati University, Guwahati, Assam India, 1-357, 1995.

[7] G.S. Robertson, M. Bolton, P. Monaghan. Influence of diet and foraging strategies on reproductive success in two morphologically similar sympatric sea birds, bird study, 63: 3, 319-329, 2016

[8] K.M. Dodge, R.C. Whitmore, E.J. Harner. Analyzing foraging use versus availability using regression techniques. Studies in Avian Biology, Vol.13, 318-324, 1999.

[9] E.C.S. Baker. The fauna of British India including Ceylon and Burma. London: Taylor \& Francis, 1929.

[10] M.A. Dada, U.F. Ahmad, M.A. Rather, N.A. Kuchhay. Topographic and geomorphological mapping of river Sindh a study of Himalayan river of Jammu \& Kashmir, International Journal of Remote Sensing \& Geoscience, Vol. 2(6), 1-7, 2013.

[11] S. Siraj. Variation in species composition and distribution of macrozoobenthos along an altitudinal gradient in Sindh river of Kashmir Himalaya. 2018.

[12] J. Altmann. The observational study of behaviour: sampling methods. Behavior, Vol. 49:227e266, 1974.

[13] P. Martin, P.P.G. Bateson, P. Bateson. Measuring behaviour: an introductory guide, Cambridge University Press, 1993.

[14] R.C. Martins, T. Catry, C.D. Santos, J.M. Palmeirim, J.P. Granadeiro. Seasonal variations in the diet and foraging behavior of Dunlins Calidris alpina in a South European Estuary: Improved feeding conditions for northward migrants, PLoS ONE, Vol. 8(12): e81174, 2013.

[15] M.C. Baker, A.E.M. Baker. Niche relationships among six species of shorebirds on their wintering and breeding ranges, Ecological monographs, Vol. 43(2), 193-212, 1973.

[16] A. Barbosa, E. Moreno. Evolution of foraging strategies in shorebirds: an ecomorphological approach. The Auk, Vol. 116(3), 712-725, 1999.

[17] K.N. Mouritsen, K.T. Jensen. Choice of microhabitat in tactile foraging dunlins Calidris alpina: The importance of sediment penetrability, Marine ecology progress series, Oldendorf, Vol. 85(1), 1-8, 1992.

[18] J.P. Pierre. Effects of sexual dimorphism on feeding behaviour of the Bar-tailed Godwit (Limosa lapponica) at a southern hemisphere wintering site, 1994.

[19] S. Nebel. Latitudinal clines in bill length and sex ratio in a migratory shorebird: a case of resource partitioning?, Acta Oecologica, Vol. 28(1), 33-38, 2005.

[20] B. Lauro, E. Nol. Feeding behavior, prey selection, and bill size of Pied and Sooty Oystercatchers in Australia, The Wilson Bulletin, 629-640, 1995.

[21] A.F.C. Gerritsen, Y.M. Van Heezik. Substrate preference and substrate related foraging behaviour in three Calidris species, Netherlands Journal of Zoology, Vol. 35(4), 671-692, 1984.

[22] N.A. Norazlimi, R. Ramli. The relationships between morphological characteristics and foraging behavior in four selected species of shorebirds and water birds utilizing tropical mudflats, The Scientific World Journal, 2015.

[23] D.J. Páez, O. Restif, P. Eby, R.K. Plowright. Optimal foraging in seasonal environments: implications for residency of Australian flying foxes in food-subsidized urban landscapes, Philosophical Transactions of the Royal Society B: Biological Sciences, Vol. 373(1745), 2018, D.O.I 20170097.

[24] A.J. Baker, P.M. Gonzalez, T. Piersma, L.J. Niles, I.D.S. do Nascimento, P.W. Atkinson, N.A. Clark, C.D. Minton, M.K. Peck, G Aarts. Rapid population decline in red knots: fitness consequences of decreased refuelling rates and late arrival in Delaware Bay. Proceedings of the Royal Society of London Series B-Biological Sciences, Vol. 271: 875-882, 2004. 